\title{
Subject Element End Date Time
}

National Cancer Institute

\section{Source}

National Cancer Institute. Subject Element End Date Time. NCI Thesaurus. Code C83410.

The date and time a subject element has concluded. 